\title{
Thidiazuron affects the quality of 'Gala' apples stored under controlled atmosphere
}

\author{
Thidiazuron afeta a qualidade de maçãs 'Gala' armazenadas sob atmosfera controlada
}

\author{
Ricardo Fabiano Hettwer Giehl ${ }^{\mathrm{I}}$ Ivan Sestari" Ana Cristina Eisermann' ${ }^{\mathrm{I}}$ Auri Brackmann ${ }^{\mathrm{II}}$
}

\section{ABSTRACT}

This work was carried out aiming to evaluate the effect of thidiazuron (TDZ) on the quality of 'Gala' apples stored under controlled atmosphere (CA) conditions. Plants were sprayed at full bloom with TDZ at 0, 10, 20, or $40 \mathrm{~g} \mathrm{ha} \mathrm{g}^{-1}$ (a.i.). Harvested fruits were then stored in $C A$ with $1.0+2.5$, $1.5+2.5$ and $1.5+5.0\left(\mathrm{kPaO} \mathrm{O}_{2}+k P a \mathrm{CO}_{2}\right)$, both at $0.5^{\circ} \mathrm{C}$. In addition, the partial pressure of $1.5 \mathrm{kPa}$ of $\mathrm{O}_{2}+2.5 \mathrm{kPa}$ of $\mathrm{CO}_{2}$ was also evaluated at $-0.5^{\circ} \mathrm{C}$. Higher flesh firmness and titratable acidity was obtained by applying 20 or $40 \mathrm{~g} \mathrm{ha}^{-1} \mathrm{TDZ}$. Furthermore, these TDZ doses decreased the respiration rate as well as the occurrence of flesh breakdown, mealiness and decay. The application of TDZ at doses ranging from 20 to $40 \mathrm{~g}$ $\mathrm{ha}^{-1}$ maintains higher fruit quality for up to 8 months under $C A$. In addition, the storage of 'Gala' apples under CA with $1.0 \mathrm{kPa} \mathrm{O}_{2}+2.5 \mathrm{kPaCO} \mathrm{CO}_{2}$ at $0.5^{\circ} \mathrm{C}$ results in higher flesh firmness and titratable acidity. Moreover, this CA condition reduces the incidence of flesh breakdown, mealiness and postharvest decay in 'Gala' apple fruits.

Key words: phenylurea, cytokinin, ethylene, postharvest.

RESUMO

O objetivo deste trabalho foi avaliar o efeito da aplicação de thidiazuron (TDZ) na qualidade de maçãs 'Gala' armazenadas em condições de atmosfera controlada (AC). Avaliou-se o efeito do TDZ nas doses de 0, 10, 20 e 40g ha-1 (i.a.), aplicadas no pleno florescimento. Após a colheita, os frutos foram armazenados em condições de AC com 1,0+2,5; $1,5+2,5$ ou 1,5+5,0 ( $k P a$ de $\mathrm{O}_{2}+k P a$ de $\mathrm{CO}_{2}$ ), ambas a $0,5^{\circ} \mathrm{C}$. Além disso, a pressão parcial de $1,5 \mathrm{kPa}$ de $\mathrm{O}_{2}+2,5 \mathrm{kPa}$ de $\mathrm{CO}_{2}$ também foi avaliada a $-0,5^{\circ} \mathrm{C}$. Doses de TDZ entre 20 e $40 \mathrm{~g}$ ha $a^{-1}$ mantiveram maior firmeza da polpa e acidez titulável. Além disso, essas mesmas doses reduziram a atividade respiratória e a incidência de degenerescência da polpa, de polpa farinhenta e de podridões. A aplicação pré-colheita de TDZ, especialmente em doses entre 20 e 40g ha-1, melhora a qualidade de maçãs 'Gala' armazenadas em AC por até oito meses. Em relação às condições de AC avaliadas, o uso de $1,0 \mathrm{kPa}$ de $\mathrm{O}_{2}+2,5 \mathrm{kPa}$ de $\mathrm{CO}_{2}$ a $0,5^{\circ} \mathrm{C}$ resultou em frutos mais firmes e com maior acidez titulável, além de menor incidência de degenerescência da polpa, de polpa farinhenta e de podridões.

Palavras-chave: feniluréia, citocinina, etileno, pós-colheita.

\section{INTRODUCTION}

Thidiazuron [TDZ; 1-fenil-3-(1,2,3-tiadiazol5-il)urea] is a phenylurea with cytokinin-like activity that regulates cell division and thereby affects many aspects of fruit development, such as growth rate and fruit shape (PETRI et al., 2001). This chemical shows many effects on plants, depending on the concentration, on the time of application and on the species and/or variety treated. Furthermore, the interaction of all aforementioned factors with the environmental conditions might significantly affect the physiological response of plants to TDZ application (AMARANTE et al., 2003).

It has been shown that when applied at low concentrations or close to the full bloom, TDZ increases effective fructification (PETRI et al., 2001; AMARANTE et al., 2002), as well as fruit growth (GREENE, 1995). However, when delayed to 22 days after full bloom, the

Institut für Pflanzenernährung, Universtät Hohenhein, Stuttgart, Alemanha

IDepartamento de Ciências Biológicas, Escola Superior de Agricultura "Luiz de Queiroz" (ESALQ), Universidade de São Paulo (USP), CP 9, 13418-900, Piracicaba, SP, Brasil. E-mail: isestari@esalq.usp.br. Autor para correspondência.

II'Departamento de Fitotecnia, Universidade Federal de Santa Maria (UFSM), Santa Maria, RS, Brasil. 
application of TDZ resulted in fruit thinning (GREENE, 1995). In addition, TDZ might also negatively impact flowering and fruit quality, since application of high doses inhibited the subsequent flowering (AMARANTE et al., 2002) and resulted in asymmetric and/or deformed fruits (PETRI et al., 2001), suggesting that the mobility and/or redistribution of TDZ into the fruit is limited.

Besides the effects described above, the application of TDZ might also affect fruit maturation (GREENE, 1995; PETRI et al., 2001; AMARANTE et al., 2003) and ripening (GREENE, 1995). The effect of TDZ on the ripening process might result from the interaction with the plant hormone ethylene, since the supply of cytokinins to Arabidopsis thaliana seedlings significantly stimulated the synthesis of ethylene (VOGEL et al., 1998). For instance, the application of TDZ on 'Gala' apples, especially at $10 \mathrm{mg}$ $\mathrm{L}^{-1}$, was able to significantly delay the ripening process, by maintaining higher flesh firmness and starch contents (PETRI et al., 2001). However, in the same experiment, TDZ had no effect on either the titratable acidity or the soluble solid. In another experiment with 'Gala' and 'Fuji' apples, the spraying of TDZ negatively affected the visual quality of the fruits by decreasing peel red color and by increasing the occurrence of asymmetric fruits (AMARANTE et al., 2003). Furthermore, TDZ-treated fruits showed higher occurrence of carperlar decay, as well as impaired sensorial quality. The last one was reflected as a reduced titratable acidity and soluble solids content in 'Gala' apples and as lower acidity in 'Fuji' apples.

As cytokinins might interact with ethylene, either by affecting its synthesis or perception in plants and fruits, it becomes important to unveil the potential benefits or drawbacks of cytokinin-like compounds, such as TDZ, on the ripening of apples, especially after long-term storage. Therefore, in the present work we aimed to investigate the impact of increasing doses of TDZ sprayed at the full bloom on the quality of 'Gala' apples stored under controlled atmosphere (CA) conditions.

\section{MATERIALS AND METHODS}

The experiment was carried out in an experimental segment of a commercial orchard (Rasip ${ }^{\circledR}$, Vacaria, RS, Brazil) during the production year 2003/ 2004. 'Gala' apple plants were sprayed with TDZ $\left(\right.$ Dropp $^{\circledR}$ ) at the full bloom stage by means of a turbo atomizer at a volume of $1000 \mathrm{~L} \mathrm{ha}^{-1}$. The experiment design was in completely randomized blocks with four repetitions, where each experimental plot was composed by six rows with 10 plants. Only the fruits from the plants located in the center of each experimental plot were harvested.

Prior to storage, apples were selected by excluding those excessively ripe or injured. The factorial design consisted of the combination of the preharvest application of four TDZ doses $\left(0,10,20\right.$ e $40 \mathrm{~g}$ a.i. ha $\left.{ }^{-1}\right)$ with four controlled atmosphere storage conditions $\left(1.0 \mathrm{kPaO}_{2}+2.5 \mathrm{kPaCO}_{2} ; 1.5 \mathrm{kPa} \mathrm{O}_{2}+2.5 \mathrm{kPaCO}_{2} ; 1.5 \mathrm{kPa}\right.$ $\mathrm{O}_{2}+5.0 \mathrm{kPaCO}_{2}$ both at $+0.5^{\circ} \mathrm{C}$; and $1.5 \mathrm{kPaO}_{2}+2.5 \mathrm{kPa}$ $\mathrm{CO}_{2}$ at $-0.5^{\circ} \mathrm{C}$ ). All the procedures regarding the installation and maintenance of both partial pressures of gases and temperatures inside the storage room were the same as described earlier by BRACKMANN et al. (2000) and CERETTA (2003).

Analyses were performed after 8 months of CA-storage plus 7 days of shelf-life at $20^{\circ} \mathrm{C}$. The physiological parameters assessed were: (a) ethylene synthesis which was determined by gas chromatography (Varian ${ }^{\circledR}, \mathrm{CX} 3400$ ) in samples collected from hermetically tight 5-liter jars containing around $1 \mathrm{~kg}$ of apples representative for each experimental sample. Results were expressed as $\mu \mathrm{L}$ ethylene $\mathrm{kg}^{-1} \mathrm{~h}^{-1}$; (b) the gas composition of the aforementioned sealed 5-liter jars was circulated through a continuous flowthrough $\mathrm{O}_{2} / \mathrm{CO}_{2}$ analyzer (Agridatalog ${ }^{\circledR}$ ). The $\mathrm{CO}_{2}$ concentrations measured were then calculated as respiration rate, expressed as $\mathrm{mL} \mathrm{CO}_{2} \mathrm{~kg}^{-1} \mathrm{~h}^{-1}$; (3) peel background color, measured by a colorimeter (Minolta ${ }^{\circledR}$, CR-310) in the CIE L*a*b* system. Results were expressed as hue angle $\left(h^{\circ}\right)$, were $h^{\circ}=\operatorname{arctang}\left(b^{*} / a^{*}\right)$, and as chrome $\left(\mathrm{C}^{*}\right)$, were $\mathrm{C}^{*}=\left[\left(\mathrm{a}^{* 2}+\mathrm{b}^{* 2}\right)^{1 / 2}\right]$. Moreover, other quality parameters, such as flesh firmness (expressed in Newton, N), titratable acidity (meq $100 \mathrm{~mL}^{-1}$ ), soluble solids content ( ${ }^{\circ}$ Brix) and the occurrence of internal breakdown, mealiness and decays (expressed as $\%$ of fruits affected) were also assessed following exactly the same procedure as described previously (BRACKMANN et al. 2000).

Data expressed as percentage was tested and showed non-normal distribution. Therefore, prior to the analysis of variance these data were transformed by $\mathrm{Y}=\operatorname{arcsen}(\mathrm{X}+0.5 / 100)^{1 / 2}$, where $\mathrm{X}=$ original values as percentage. Firstly, the existence of interactions for preharvest-applied TDZ concentrations and CA storage conditions were tested. Since no interaction was significant at $5 \%$ level for any of the parameters evaluated, the means of each treatment were compared by Duncan's test at 5\% level.

Ciência Rural, v.40, n.4, abr, 2010. 


\section{RESULTS AND DISCUSSION}

After 8 months of CA storage plus 7 days of shelf-life at $20^{\circ} \mathrm{C}$, no significant interaction for preharvest application of TDZ and CA storage conditions were detected by ANOVA at $\mathrm{P} \leq 0.05$. The preharvest application of 20 and $40 \mathrm{~g} \mathrm{ha}^{-1}$ of TDZ significantly reduced fruit respiration immediately after the removal of fruits from the controlled atmosphere storage (Figure 1A). While fruits treated with $20 \mathrm{~g} \mathrm{ha}^{-1}$ TDZ showed lower respiration rate (Figure 1B), those treated with $10 \mathrm{~g} \mathrm{ha}^{-1} \mathrm{TDZ}$ had lower ethylene synthesis after 7 days of shelf-life (Figure 1C). Although cytokinins are able to delay leaf senescence, little is known about their effects on fruit ripening. It has been reported that in some plant tissues cytokinins stimulate ethylene biosynthesis. For instance, in seedlings of Arabidopsis thaliana, the supply of cytokinin increased ethylene production possibly by enhancing the stability and/or the activity of one ACC synthase isoform (VOGEL et al., 1998). However, regarding the positive effects of TDZ in reducing fruit respiration rates as observed herein, there is no report in the literature linking cytokinins with the direct control of respiration.

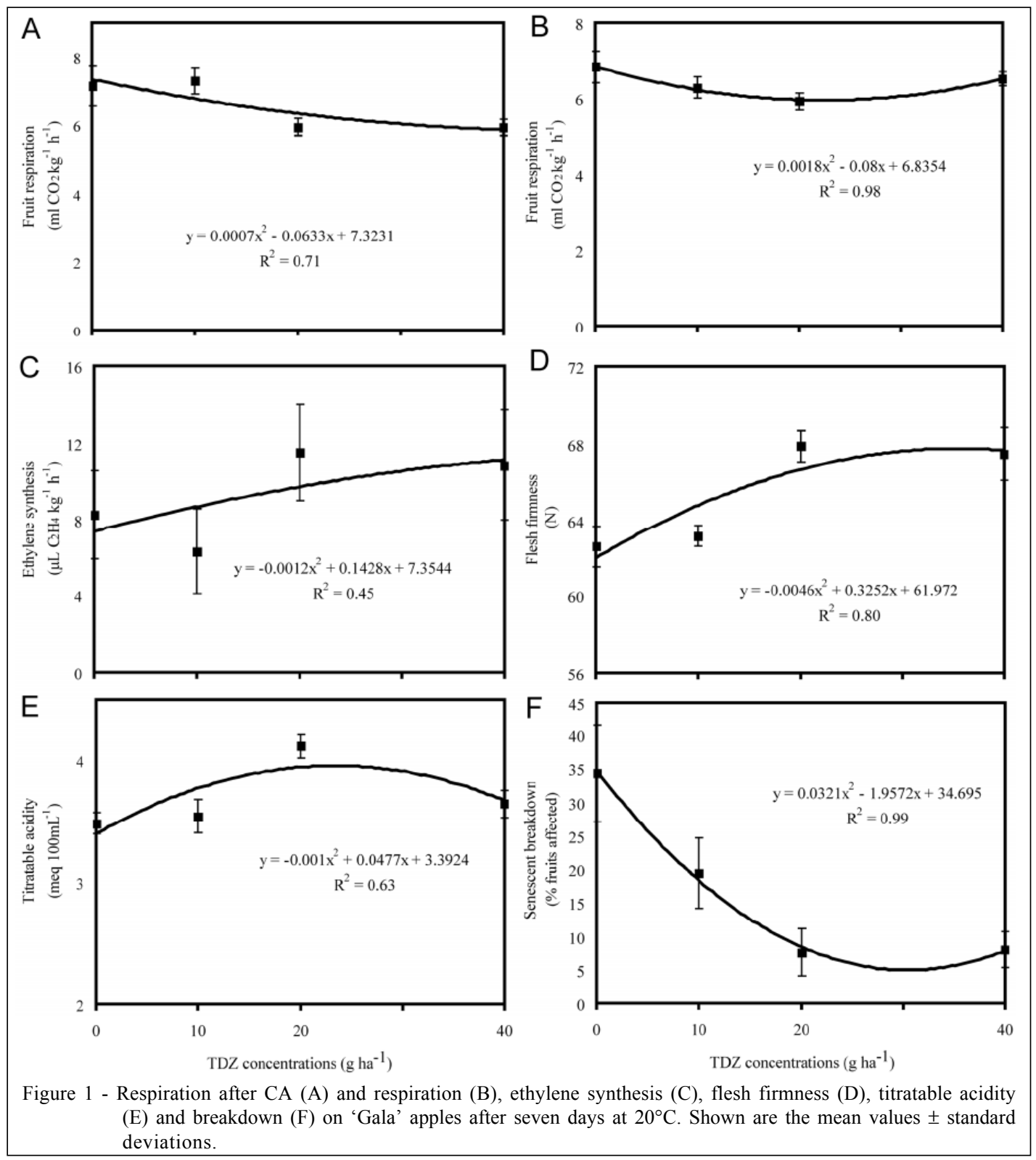

Ciência Rural, v.40, n.4, abr, 2010. 
Higher flesh firmness and titratable acidity were obtained with the application of TDZ, mainly when 20 to $40 \mathrm{~g} \mathrm{ha}^{-1}$ were applied (Figures 1D and 1E). The higher acidity observed in TDZ-treated fruits was probably due to the reduced respiratory activity of these fruits (Figure 1E). However, these results are in contrast with those reported by AMARANTE et al. (2003) in which increasing concentrations of TDZ reduced significantly fruit acidity. Regarding flesh firmness, it was also reported in an earlier study that the application of TDZ in 'Gala' apple trees resulted in fruits with higher flesh firmness at the harvest (PETRI et al., 2001). In another study, however, the application of this compound again on 'Gala' apple trees at the full-boom did not significantly affect the flesh firmness of the fruits at the harvest (AMARANTE et al., 2003). These contradictions might indicate that other as yet uncharacterized factors may also interfere with TDZ to affect the flesh firmness of 'Gala' apples both at harvest and after storage.

The occurrence of flesh breakdown, mealiness and decays were significantly reduced by treating fruits at the preharvest with TDZ, especially when 20 or $40 \mathrm{~g} \mathrm{ha}^{-1}$ was used (Figures 1F, 2A and 2B).
These results might indicate that the efficiency of TDZ in controlling decay and physiological disorders in 'Gala' apples is highly dependent on the dose that is chosen. When applied at the full-bloom stage, higher doses of TDZ increased occurrence of decay in the carpelar cavity both in 'Gala' and 'Fuji' apples (AMARANTE et al., 2003). These negative effects of TDZ might be related to the reduced concentrations of calcium in TDZ-treated apple fruits (PETRI et al., 2001; AMARANTE et al., 2002). Whether the reduced occurrence of decay and physiological disorders reported herein were exclusively due to the TDZinduced reduction of respiration and/or ethylene synthesis remains to be unveiled.

The preharvest application of TDZ resulted in 'Gala' apples with greener peel background color, as demonstrated by the highest values of hue angle $\left({ }^{\circ} \mathrm{h}\right)$ measured in TDZ-treated fruits after storage (Figure $2 \mathrm{C})$. However, color purity, expressed as chrome ( $\left.\mathrm{C}^{*}\right)$, was not significantly changed in response to TDZ, independently of the concentration used (Figure 2D).

Besides evaluating the effect of the application of the cytokinin-like compound TDZ, the effect of controlled atmosphere conditions on the
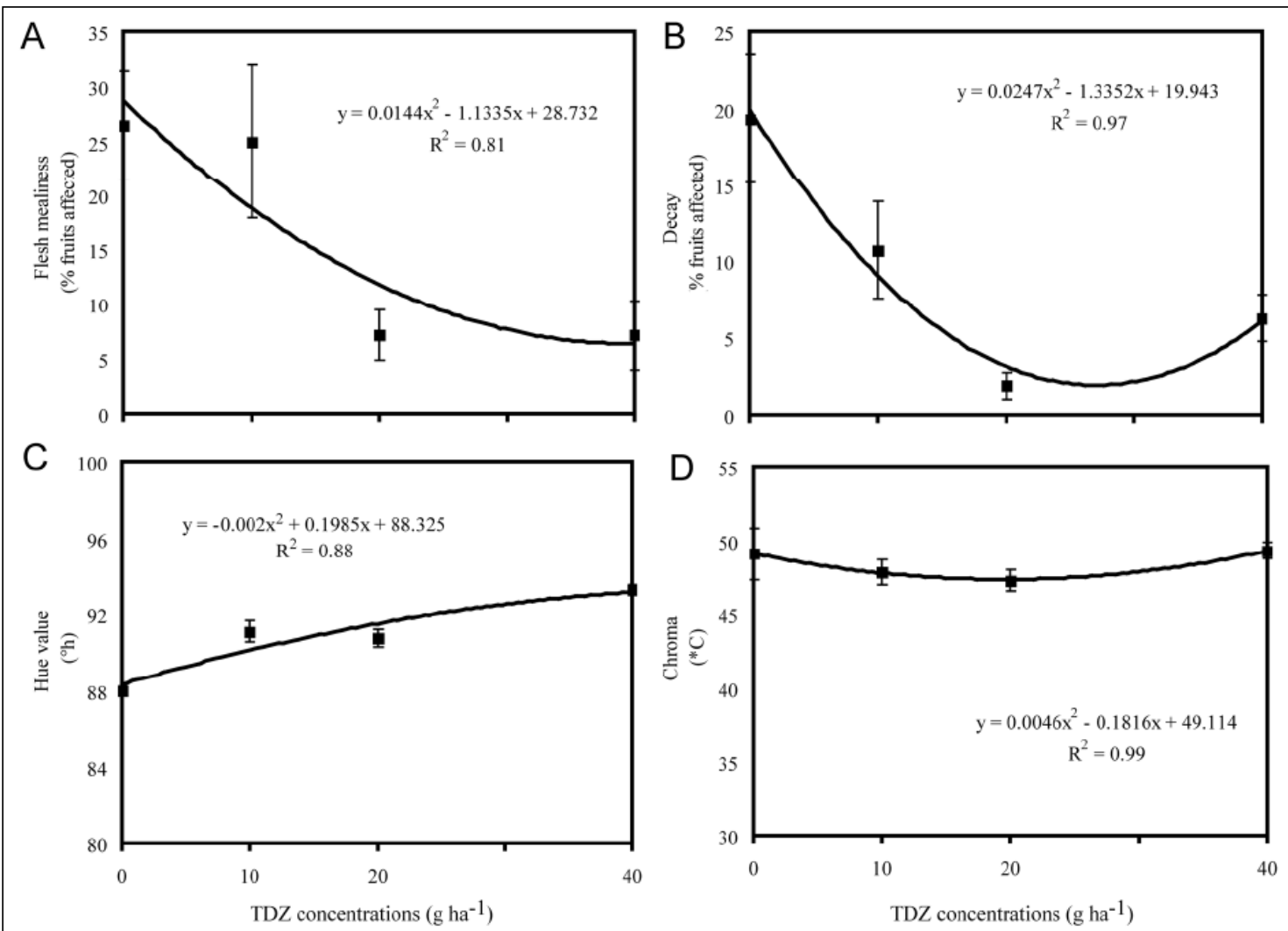

Figure 2 - Flesh mealiness (A) decay (B) and peel color, represented as hue angle (C) and Chroma values (D) on 'Gala' apples after seven days at $20^{\circ} \mathrm{C}$. Shown are the mean values \pm standard deviations.

Ciência Rural, v.40, n.4, abr, 2010. 
maintenance of postharvest quality of 'Gala' apples was also assessed. Reduced ethylene synthesis was observed in fruits stored under $1.5 \mathrm{kPa} \mathrm{O}_{2}+2.5 \mathrm{kPa} \mathrm{CO}$ at $-0.5^{\circ} \mathrm{C}$ (Figure $3 \mathrm{~A}$ ). These levels of synthesis were, however, similar to those produced by fruits stored at $0.5^{\circ} \mathrm{C}$ under $1.5 \mathrm{kPa} \mathrm{O}+2.5 \mathrm{kPa} \mathrm{CO}$ at removal from storage. After seven days of shelf-life, whereas the apples stored under $1.0 \mathrm{kPa} \mathrm{O}_{2}+5.0 \mathrm{kPa} \mathrm{CO}_{2}$ at $0.5^{\circ} \mathrm{C}$ showed higher ethylene synthesis, those stored under $1.5 \mathrm{kPa} \mathrm{O}_{2}+2.5 \mathrm{kPa} \mathrm{CO}_{2}$ at $-0.5^{\circ} \mathrm{C}$ had lower levels of synthesis. In fact, it has been shown that the expression and the activity of the main enzymes involved in ethylene synthesis, namely ACC synthase and of ACC oxidase, can be delayed by storing fruits under low temperatures combined with either low levels of $\mathrm{O}_{2}$ or high levels of $\mathrm{CO}_{2}$ (GORNY \& KADER, 1996; MATHOOKO et al., 2001). Therefore, the aforementioned storage condition was possibly able to delay the onset of the "auto-catalyctic" synthesis of ethylene. Fruit stored under $\mathrm{CA}$ with $1.0 \mathrm{kPa}$ $\mathrm{O}_{2}+2.5 \mathrm{kPa} \mathrm{CO}_{2}$ at both temperatures showed lower respiration rates after 7 days of simulated shelf-life at $20^{\circ} \mathrm{C}$ (Figure 3B). According to LIU et al. (2004), the activity of isocitrate dehidrogenase is inhibited by $\mathrm{CO}_{2}$. This enzyme is responsible for the conversion of isocitrate to 2-oxoglutarate in the tricarboxylic acid cycle. The storage of apples under $1.5 \mathrm{kPa} \mathrm{O}+2.5 \mathrm{kPa}$ $\mathrm{CO}_{2}$ at $-0.5^{\circ} \mathrm{C}$ resulted also in low levels of ethylene synthesis after 7 days of shelf-life, as mentioned above (Figure 3A). Since the biosynthesis of ethylene demands ATP, which is generated in e.g. the respiration process (WILD et al., 1999), the reduced production of ethylene observed in apples stored under $1.0 \mathrm{kPa}$ $\mathrm{O}+2.5 \mathrm{kPa} \mathrm{CO}_{2}$ at $-0.5^{\circ} \mathrm{C}$ might be, at least in part, due to the low respiration levels recorded on these fruits.

The storage of 'Gala' apples under CA with $1.0 \mathrm{kPa} \mathrm{O}+2.5 \mathrm{kPaCO}$ reduced fruit softening, expressed as higher flesh firmness, although this result did not differ statistically from storage under $1.5 \mathrm{kPa}$ $\mathrm{O}_{2}+5.0 \mathrm{kPa} \mathrm{CO}$ and $1.5 \mathrm{kPa} \mathrm{O}_{2}+2.5 \mathrm{kPa} \mathrm{CO}_{2}$ at $-0.5^{\circ} \mathrm{C}$ (Table 1). The best CA condition for 'Gala' apples produced in Brazil has been indicated as $1.0 \mathrm{kPa}$ of $\mathrm{O}_{2}$ combined with $\mathrm{CO}_{2}$ levels ranging from 2.0 to $3.0 \mathrm{kPa}$ (SAQUET et al., 1997). The loss of flesh firmness in apples during the storage is most likely the result of the breakdown of structural bridges between hemicelluloses and pectins by cell-wall-hydrolyzing enzymes (SIDDIQUI et al., 1996). The activity of many of these enzymes, in turn, is strongly affected by CA conditions (ZHOU et al., 2000).

Apples stored under CA with $1.0 \mathrm{kPa}$ $\mathrm{O}_{2}+2.5 \mathrm{kPaCO}$ had higher titratable acidity (Table 1). This result might also be due to the low respiration activity of these fruits, since low respiration activity reduced the consumption of malic acid by the activity of the malic enzyme in the tricarboxylic acid cycle (GOODENOUGH et al., 1985). The soluble solids content, however, was higher in apples stored at $0.5^{\circ} \mathrm{C}$ under $1.0 \mathrm{kPa} \mathrm{O}_{2}+2.5 \mathrm{kPaCO}_{2}$, even though not differing statistically from those stored under $1.5 \mathrm{kPa} \mathrm{O}_{2}+5.0 \mathrm{kPa}$ $\mathrm{CO}_{2}$ (Table 1).

The storage conditions tested in this experiment did not significantly affect the peel background color of fruits, expressed as hue angle $\left({ }^{\circ} \mathrm{h}\right)$ (Table 1). However, the storage of apples under CA $1.5 \mathrm{kPa} \mathrm{O}+5.0 \mathrm{kPa} \mathrm{CO}$ kept higher values of chroma (Table 1). In agreement with this observation, it has been reported that the loss of green color in 'Gala' apples may be delayed by the storage under high $\mathrm{CO}_{2}$ levels (3.0 to 4.0kPa) (BRACKMANN et al., 2000).

Flesh breakdown was efficiently reduced through $\mathrm{CA}$ storage at $0.5^{\circ} \mathrm{C}$ under $1.0 \mathrm{kPa} \mathrm{O}+2.5 \mathrm{kPa}$ $\mathrm{CO}_{2}$ and $1.5 \mathrm{kPaO}+5.0 \mathrm{kPaCO}_{2}$ (Table 1). Considering the effect of the two storage temperatures tested, it was observed that the storage under $-0.5^{\circ} \mathrm{C}$ resulted in increased flesh breakdown. In this regard, CERETTA

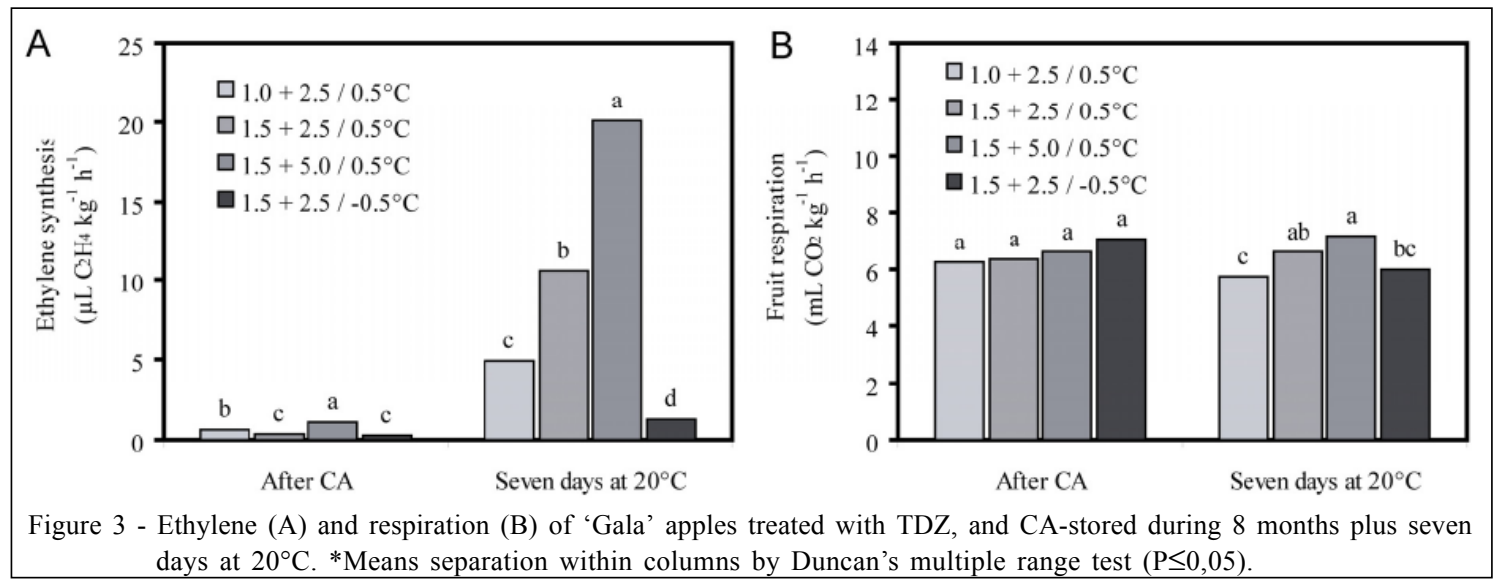

Ciência Rural, v.40, n.4, abr, 2010. 
Table 1 - Quality of 'Gala' apples treated with TDZ following CA storage during 8 months plus seven days at $20^{\circ} \mathrm{C}$.

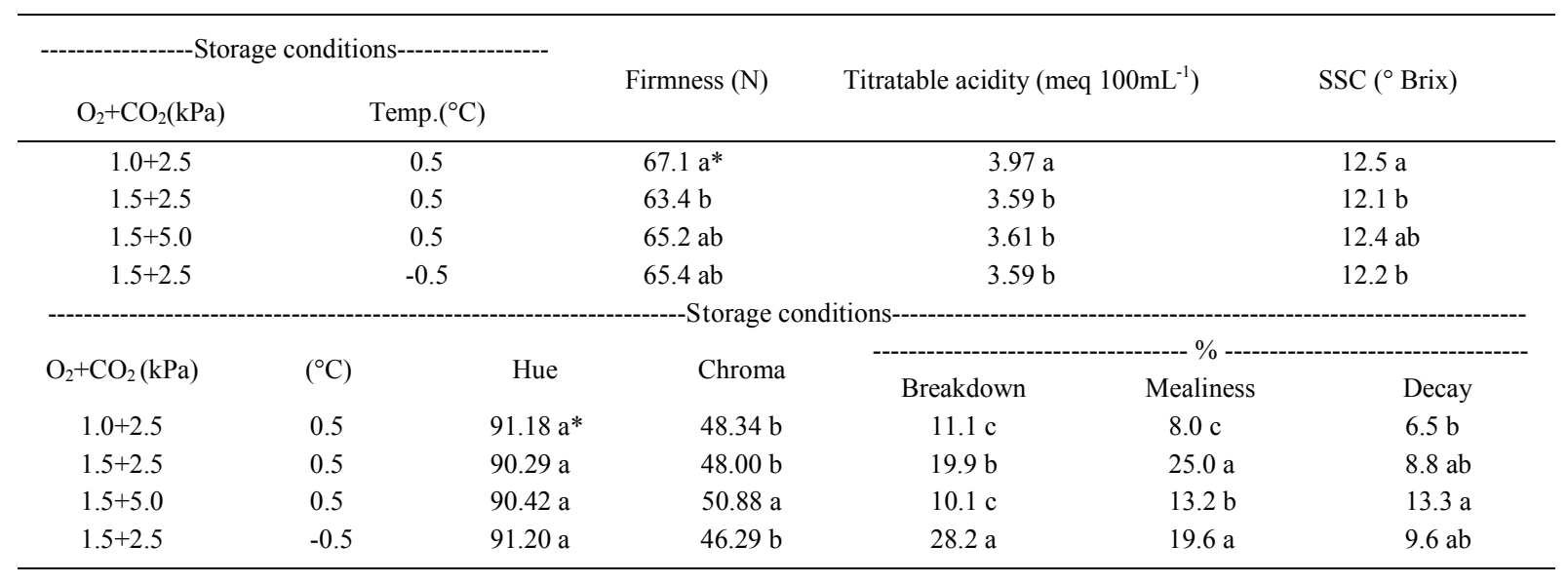

* Means separation within columns by Duncan's multiple range test $(\mathrm{P} \leq 0,05)$.

(2003) observed that flesh breakdown in 'Gala' apples was significantly increased when the temperature was decreased from $0^{\circ} \mathrm{C}$ to -0.8 or $-1.6^{\circ} \mathrm{C}$.

A reduced occurrence of mealiness in fruits stored under $1.0 \mathrm{kPa} \mathrm{O}+2.5 \mathrm{kPa} \mathrm{CO}_{2}$ at $0.5^{\circ} \mathrm{C}$ was observed (Table 1). The development of mealiness in apples has been associated with reduced cell adhesion in the flesh, possibly due to an enhanced dissolution of pectins in the middle lamella and a relatively high resistance to cell "ruptures" (HARKER \& HALLETT, 1992). According to ZHOU et al. (2000), high $\mathrm{CO}_{2}$ and low $\mathrm{O}_{2}$ levels can reduce the activity of polygalacturonases, which are the enzymes responsible for the hydrolysis of pectins from the cell wall. The storage of apples under $1.0 \mathrm{kPa} \mathrm{O}_{2}+2.5 \mathrm{kPa}$ $\mathrm{CO}_{2}$ at $0.5^{\circ} \mathrm{C}$ (Table 1 ) reduced the incidence of decay, although this effect did only differ statistically from the storage under $1.5 \mathrm{kPa} \mathrm{O}_{2}+5.0 \mathrm{kPa} \mathrm{CO}_{2}$ (Table 1).

\section{CONCLUSIONS}

The preharvest treatment of 'Gala' apples with thidiazuron (TDZ), especially at $20 \mathrm{~g} \mathrm{ha}^{-1}$ improves the postharvest quality up to 8 months under controlled atmosphere (CA).

CA storage of 'Gala' apples under $1.0 \mathrm{kPa}$ $\mathrm{O}_{2}+2.5 \mathrm{kPa} \mathrm{CO}_{2}$ at $0.5^{\circ} \mathrm{C}$ results in higher flesh firmness and titratable acidity levels. Furthermore, this condition markedly reduces the incidence of flesh breakdown, mealiness and decay.

\section{REFERENCES}

AMARANTE, C.V.T. et al. Thidiazuron effects on shoot growth, return bloom, fruit set and nutrition of apples.
Pesquisa Agropecuária Brasileira, v.37, n.10, p.13651371, 2002. Disponível em: <http://dx.doi.org/10.1590/ S0100-204X2002001000003>. Acesso em: 18 jun. 2009. doi: 10.1590/S0100-204X2002001000003.

AMARANTE, C.V.T. et al. Effect of preharvest spraying with Thidiazuron on fruit quality and maturity of apples. Revista Brasileira de Fruticultura, v.25, n.1, p.59-62, 2003. Disponível em: <http://dx.doi.org/10.1590/S010029452003000100018>. Acesso em: 18 jun. 2009. doi: 10.1590/ S0100-29452003000100018.

BRACKMANN, A. et al. Qualidade de maçãs 'Gala' armazenadas em diferentes pressões parciais de $\mathrm{O}_{2}$ e $\mathrm{CO}_{2}$. Scientia Agricola, v.57, n.2, p.195-198, 2000. Disponível em: <http://dx.doi.org/ 10.1590/S0103-90162000000200001>. Acesso em: 18 jun. 2009. doi: 10.1590/S0103-90162000000200001.

CERETTA, M. Tolerância de maçãs 'Gala' e 'Fuji' a baixas temperaturas e extremas pressões parciais de $\mathrm{O}_{2}$ e $\mathrm{CO}_{2}$ durante o armazenamento em atmosfera controlada. 2003. 70f. Tese (Doutorado) - Universidade Federal de Pelotas, Pelotas, RS.

WILD, H.P.J. de. et al. Carbon dioxide and 1-MCP inhibit ethylene production and respiration of pear fruit by different mechanisms. Journal of Experimental Botany, v.50, n.355, p.837-844, 1999. Disponível em: <http://dx.doi.org/10.1093/ jexbot/50.335.837>. Acesso em: 18 jun. 2009. doi: 10.1093/ jexbot/50.335.837.

GOODENOUGH, P.W. et al. NADP-linked malic enzyme and malate metabolism in ageing tomato fruit. Phytochemistry, v.24, p.1157-1162, 1985. Disponível em: <http://dx.doi.org/ 10.1016/S0031-9422(00)81093-6>. Acesso em: 18 jun. 2009. doi: $10.1016 / \mathrm{S} 0031-9422(00) 81093-6$.

GORNY, J.R.; KADER, A.A. Regulation of ethylene biosynthesis on climacteric apple fruit by elevated $\mathrm{CO}_{2}$ and reduced $\mathrm{O}_{2}$ atmospheres. Postharvest Biology and Technology, v.9, p.311-323, 1996. Disponível em: <http:// dx.doi.org/10.1016/S0925-5214(96)00040-3>. Acesso em: 18 jun. 2009. doi: 10.1016/S0925-5214(96)00040-3.

Ciência Rural, v.40, n.4, abr, 2010. 
GREENE, D.W. Thidiazuron effects on fruit set, fruit quality and return bloom of apples. HortScience, v.30, n.6, p.12381240, 1995.

HARKER, F.R.; HALLETT, I.C. Physiological changes associated with development of mealiness of apple fruit during cool storage. HortScience, v.27, n.12, p.1291-1294, 1992.

LIU, S. et al. Effects of $\mathrm{CO}_{2}$ on respiratory metabolism in ripening banana fruit. Postharvest Biology and Technology, v.33, n.1, p.27-34, 2004. Disponível em: <http://dx.doi.org/ 10.1016/j.postharvbio.2004.01.006>. Acesso em: 18 jun. 2009. doi: 10.1016/j.postharvbio.2004.01.006.

MATHOOKO, F.M. et al. Regulation of genes encoding ethylene biosynthetic enzymes in peach (Prunus persica L.) fruit by carbon dioxide and 1-methylcyclopropene. Postharvest Biology and Technology, v.21, n.3, p.265-281, 2001. Disponível em: <http://dx.doi.org/10.1016/S09255214(00)00158-7>. Acesso em: 18 jun. 2009. doi: 10.1016/ S0925-5214(00)00158-7.

PETRI, J.L. et al. Efeito do Thidiazuron (TDZ) na frutificação de fruteiras de clima temperado. Revista Brasileira de Fruticultura, v.23, n.3, p.513-517, 2001. Disponível em: <http:/
/dx.doi.org/10.1590/S0100-29452001000300012>. Acesso em: 18 jun. 2009 . doi: 10.1590/S0100-29452001000300012.

SAQUET, A.A. et al. Armazenamento de maçãs 'Gala' sob diferentes temperaturas e concentrações de oxigênio e gás carbônico. Ciência Rural, v.27, n.3, p.399-405, 1997. Disponível em: $\quad<\mathrm{http} / / / \mathrm{dx}$.doi.org/10.1590/S010384781997000300006>. Acesso em: 18 jun. 2009. doi: 10.1590/S0103-84781997000300006.

SIDDIQUI, S. et al. Controlled atmosphere storage of apples: cell wall composition and fruit softening. Journal of Horticultural Science, v.71, n.4, p.613-620, 1996.

VOGEL, J.E. et al. Isolation and characterization of Arabidopsis mutants defective in the induction of ethylene biosynthesis by cytokinin. Genetics, v.149, p.417-427, 1998.

ZHOU, H.W. et al. Delayed storage and controlled atmosphere storage of nectarines: two strategies to prevent woolliness. Postharvest Biology and Technology, v.18, n.2, p.133-141, 2000. Disponível em: $<\mathrm{http}: / / \mathrm{dx}$.doi.org/10.1016/S09255214(99)00072-1>. Acesso em: 18 jun. 2009. doi: 10.1016/ S0925-5214(99)00072-1. 